Agro-Science Journal of Tropical Agriculture, Food, Environment and Extension Volume 13 Number 1 January 2014 pp. 37 - 43

ISSN III9-7455

\title{
VEGETATIVE PROPAGATION OF AFRICAN WALNUT (PLUKENETIA CONOPHORA) USING PRE-TREATED STEM CUTTINGS OF VARIED PHYSIOLOGICAL AGES
}

\author{
Agbo ${ }^{1}$ E A; Ugese $^{2}$ F U. and Baiyeri ${ }^{3} P$ K \\ ${ }^{1}$ Dept. of Crop Science, University Nigeria, Nsukka, Enugu State, Nigeria; \\ ${ }^{2}$ Dept. of Crop Production, University of Agriculture, Makurdi, Benue State, Nigeria; \\ ${ }^{3}$ Dept. of Crop Science, University of Nigeria, Nsukka, Enugu State, Nigeria \\ Corresponding author: paul.baiyeri@unn.edu.ng
}

\begin{abstract}
The effect of physiological age of stem cuttings and pre-planting treatment on adventitious root and shoot growth of stem cuttings of African walnut (Plukenetia conophora) were investigated at Nsukka, Nigeria in 2012. Nodal cuttings of semi-hardwood and softwood categories were dipped in water and coconut water for 30 minutes before planting. Cuttings used as control treatment were neither dipped in water nor coconut water. Factorial combinations of age of stem cutting and pre-planting treatment were arranged in completely randomized design (CRD) and replicated three times. Results of analysis of variance (ANOVA) indicated a non-significant main effect of age of stem cutting and pre-planting treatment on number of days to breaking of dormancy and shoot formation. Physiological age of cuttings significantly $(p<0.05)$ influenced number of shoots formed, length of vine and number of leaves in favour of the semi-hardwood cuttings. Significant interaction between age of cuttings and pre-planting treatment was observed on percentage of cuttings with shoot and number of shoots per cutting. While semi-hardwood cuttings gave higher number of shoot when dipped in water, softwood cuttings (at 2- 4WAP) did better when dipped in coconut water. Available data suggest that softwood cuttings of this species are more amenable to clonal propagation. However, if semihardwood cuttings must be used, then dipping in water becomes a necessity. Evidences from this study affirm the practicability of clonal propagation of $P$. conophora via stem cuttings.
\end{abstract}

Key words: African walnut, Pre-treatment, Vegetative propagation, Stem cuttings.

\section{INTRODUCTION}

African walnut (Plukenetia conophora) is a perennial climber of the family Euphorbiaceae (Amaeze et al. 2011). The species is extensively distributed in Southern Nigeria (Egarhevba et al. 2005) where its seeds are also widely consumed (Akpuaka and Nwankor, 2000). Local trading in the seeds of the African walnut has been reported to improve the incomes of rural inhabitants (Egarhevba et al. 2005). Plukenetia conophra possesses a lot of nutritional and medicinal properties. Its food value is supported by results of proximate analysis of the seed which revealed a high protein content of $29.09 \%$ and a lipid content of close to 50\% (Enujiugha, 2003). The seed protein has a full complement of essential and nonessential amino acids (Gbadamosi et al., 2012; Udeonyia et al., 2014), which compares favourably with those of some cultivated species. In native medicinal practice, the nuts and leaves have been found useful in the treatment of male infertility and dysentery (Ajaiyeoba and Fadare, 2006). Asthmatic and hypertensive conditions could also be addressed using macerated leaves and roots of conophor (Okafor and Okorie, 1990). The roots are useful in curing chronic cough (Ayoola et al., 2011)

In the recent time, research focus has been on agroforestry, which holds the key to multi-functional agriculture (Leakey, 2009). Fortunately, Plukenetia conohora is typically an agroforestry species. This is because it is a climber and normally needs the support of other trees to climb. But since after climbing, it normally dominates the canopy of the tree providing support, it is normally planted in association with trees whose main economic part may not be the fruit (Babaloa, 2011), although this is not a rule since there are reported cases of planting this species with citrus in south western Nigeria.

The usefulness of conophor notwithstanding, it is yet to be fully domesticated (Egarhevba et al., 2005; Ayoola et al., 2011). Although there is nothing to suggest any difficulty in propagating the species from seed, yet certain factors could make vegetative propagation imperative. These include early fruiting, 
higher yields, better quality products and product uniformity arising from trueness to type of resulting plants (Leakey and Akinnifesi, 2008). In some cases, individuals with superior and rare qualities such as extended fruiting phenology, early or late fruiting may be propagated vegetatively to take advantage of such traits thereby leading to enhanced productivity of the entire agroforestry system.

In vegetative propagation, the use of growth promoting substances to initiate rooting is sometimes essential especially in difficult to root species (Kozlowski, 1971; Oladokun and Ajolo, 1996). In this regard, coconut water is reported to be rich in plant growth hormones such as auxins, gibberellins and cytokinins (Mamaril et al., 1988). Seeds of Plukenetia conophora have been shown to have high amounts of protein and lipids to warrant commercial exploitation especially under the domesticated state. To take advantage of benefits accruing from vegetative propagation, it was decided to test the response of the species to two physiological stages of cuttings (soft and semi hardwood) dipped in coconut water and water.

\section{MATERIALS AND METHODS}

Cuttings from Edem-Ani, Enugu State, Nigeria were used for the study. Stem cuttings were grouped into semi-hardwood and softwood categories based on physiological age of the cuttings. Nodal cuttings containing three (3) buds each were employed. The stem cuttings were dipped for 30 minutes in preplanting treatments comprising pure water and coconut water and a control involving no dipping of cuttings. The experimental design was a 2 x 3 factorial comprising physiological age of stem cuttings and pre-planting treatment as factors as indicated above. This was arranged in completely randomized design (CRD) and replicated three times. (plate1) Five cuttings per treatment combination were planted at a spacing of $4 \mathrm{~cm}$ apart in nursery bags filled with thoroughly weathered sawdust. Data were collected as from $2-8$ weeks after planting (WAP) on days to breaking of first bud and aspects of shoot, leaf and root growth. Data collected were subjected to analysis of variance (ANOVA) using the Genstat software (GENSTAT, 2008). Where appropriate, separation of means was by the use of FLSD at $5 \%$ level of probability.

\section{RESULTS}

Main effects of physiological age of cuttings and preplanting treatment on days to breaking of dormancy and days to shoot formation were not significant (Table 1). Table 2 summarises effect of physiological age of cuttings and pre-planting treatments on seedling growth attributes. Percentage of cuttings with shoots responded significantly $(\mathrm{p}<0.05)$ to physiological age of cutting with softwood cuttings recording higher values for the period of observation (2 - 8 WAP). Length of vine per cutting showed significant response only at $2 \mathrm{WAP}$. However, in the weeks that did not show significant response, softwood cuttings tended towards higher values of vine length.

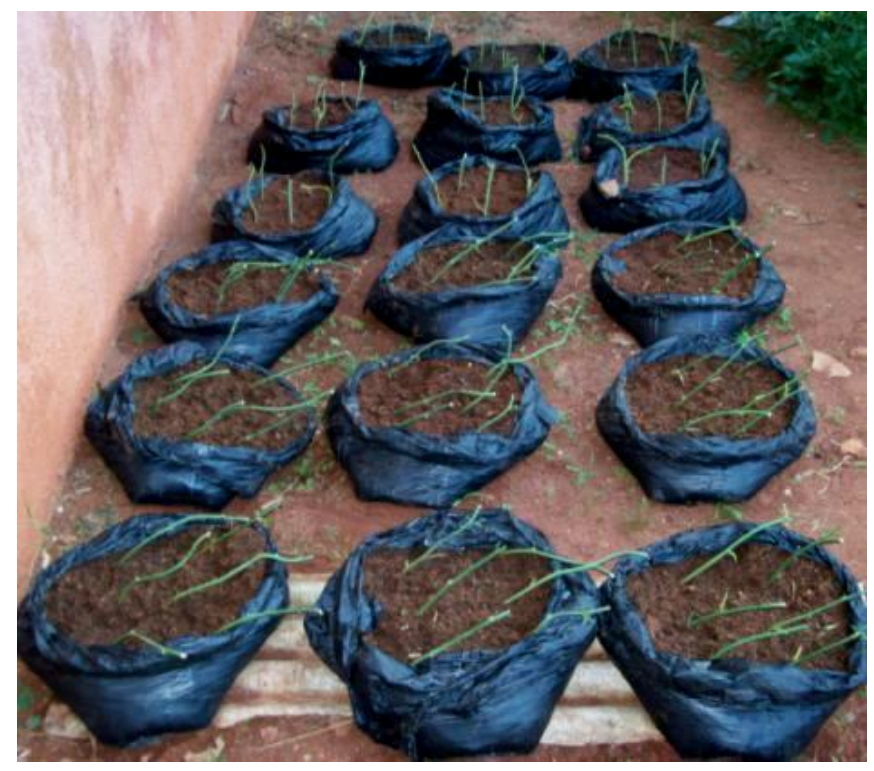

Plate 1. Experimental layout of the cuttings 
Agbo E A; Ugese F U. and Baiyeri P K

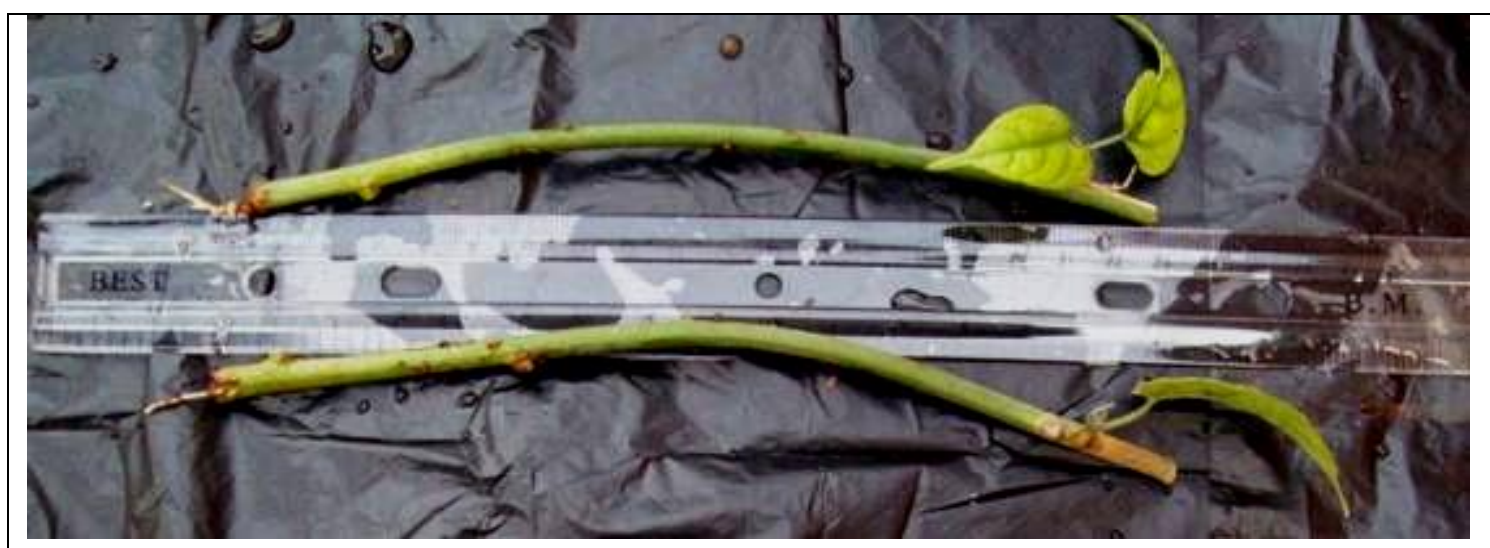

Semi-hardwood cuttings of $P$. conophora soaked in coconut water for 30 minutes

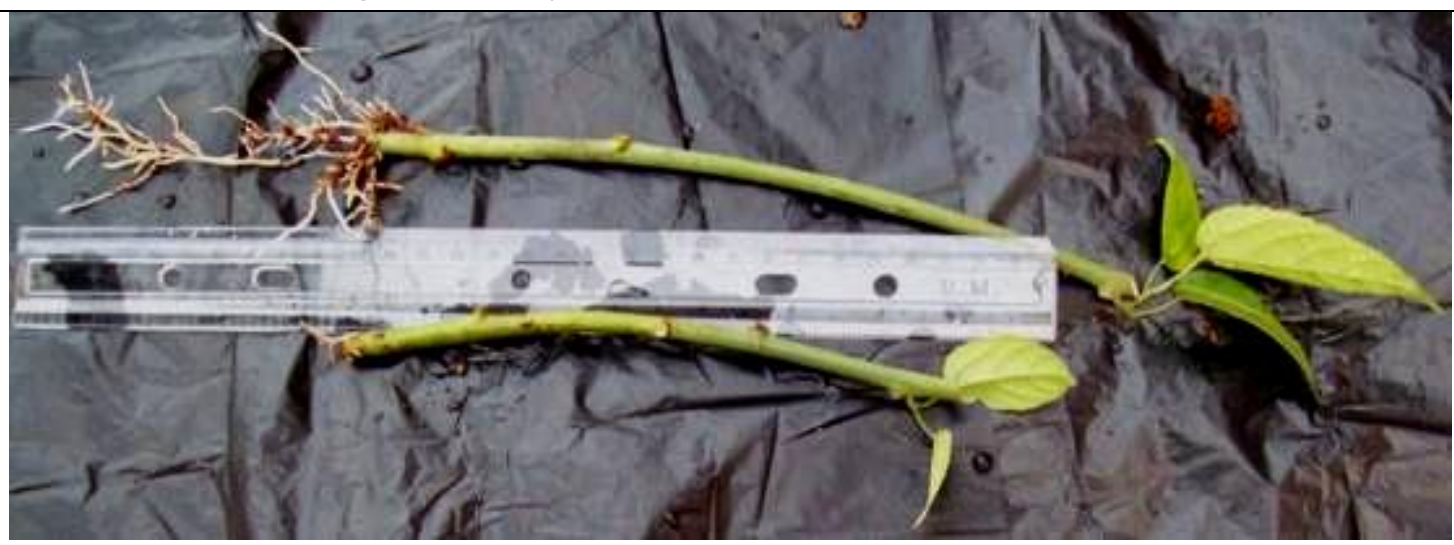

Semi-hardwood cuttings of $P$. conophora soaked in water for 30 minutes

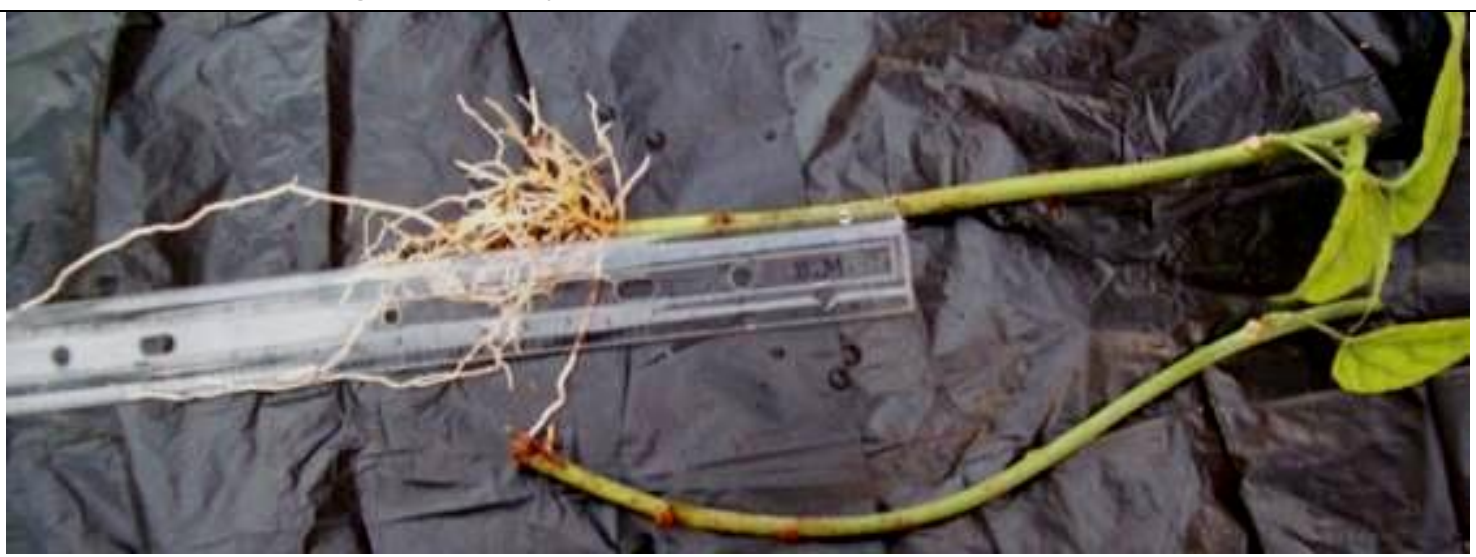

Semi-hardwood cuttings of $P$. conophora un-soaked control

Plate 2: Rooting response of $P$. conophorum to pre-planting treatment

Table 1: Effect of Physiological Age of Cuttings and Pre-Sowing Treatments on Breaking of First Bud and Shoot Development.

\begin{tabular}{lll}
\hline Cuttings & Days to breaking of the first bud & Days of shoot formation \\
\hline Semi-hardwood & 8.4 & 10.2 \\
Softwood & 9.6 & 12.4 \\
LSD $(0.05)$ & NS & NS \\
Pre-sowing treatments & & \\
Control & 8.4 & 10.4 \\
Water & 7.8 & 9.8 \\
Coconut & 10.8 & 13.7 \\
LSD $_{(0.05)}$ & NS & NS \\
\hline
\end{tabular}


TABLE 2: Effect of physiological age of cuttings and pre-sowing treatments on percentage of cuttings with shoots, number of shoots/cuttings, length of vine(shoot)/cutting and number of leaves/vine over the eight weeks of planting.

\begin{tabular}{|c|c|c|c|c|c|c|c|c|c|c|c|c|c|c|c|c|c|c|}
\hline \multirow[t]{2}{*}{$\begin{array}{l}\text { Cuttin } \\
\text { gs }\end{array}$} & $\% \mathrm{cu}$ & ngs w & h shoot & & $\begin{array}{l}\text { Numl } \\
\text { cuttin }\end{array}$ & r of sh & ots per & & Lengt & f vine & r cuttin & & $\begin{array}{l}\text { Numb } \\
\text { per sh }\end{array}$ & $\begin{array}{l}\text { r of lea } \\
\text { ot }\end{array}$ & & & \multirow[t]{2}{*}{$\begin{array}{l}\text { Numbe } \\
\text { r of } \\
\text { root/ } \\
\text { cutting } \\
\text { at } \\
\text { 8WAP } \\
8 \\
\end{array}$} & \multirow[t]{2}{*}{ 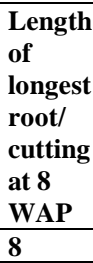 } \\
\hline & 2 & 4 & 6 & 8 & 2 & 4 & 6 & 8 & 2 & 4 & 6 & 8 & 2 & 4 & 6 & 8 & & \\
\hline $\begin{array}{l}\text { Semi- } \\
\text { hard } \\
\text { wood }\end{array}$ & 8.9 & 62.2 & 64.4 & 64.4 & 0.04 & 0.73 & 0.76 & 0.76 & 0.00 & 0.53 & 0.76 & 0.852 & 0.00 & 0.44 & 0.69 & 0.76 & 0.27 & 0.36 \\
\hline $\begin{array}{l}\text { Softwo } \\
\text { od }\end{array}$ & 33.3 & 80.0 & 95.6 & 95.6 & 0.61 & 1.31 & 1.36 & 1.36 & 0.07 & 0.72 & 0.84 & 0.89 & 0.16 & 1.21 & 1.25 & 1.27 & 0.86 & 1.34 \\
\hline $\begin{array}{l}\operatorname{LSD}(0 . \\
05)\end{array}$ & 8.39 & NS & $\begin{array}{l}13.6 \\
9\end{array}$ & $\begin{array}{l}13.6 \\
9\end{array}$ & 0.16 & 0.27 & 0.28 & 0.28 & 0.54 & NS & NS & NS & 0.11 & 0.35 & 0.38 & 0.43 & NS & NS \\
\hline $\begin{array}{l}\text { Pre-so } \\
\text { wing } \\
\text { treatm } \\
\text { ents }\end{array}$ & & & & & & & & & & & & & & & & & & \\
\hline Control & 26.7 & 66.7 & 73.3 & 73.3 & 0.45 & 0.9 & 0.9 & 0.9 & 0.061 & 0.63 & 0.84 & 0.91 & 0.07 & 0.91 & 1.09 & 1.24 & 0.96 & 1.93 \\
\hline Water & 16.7 & 83.3 & 90 & 90 & 0.27 & 1.17 & 1.23 & 1.23 & 0.037 & 0.79 & 0.82 & 0.92 & 0.17 & 0.99 & 1.03 & 1.11 & 0.43 & 0.45 \\
\hline $\begin{array}{l}\text { Coconu } \\
\text { t water }\end{array}$ & 20.0 & 63.3 & 76.7 & 76.7 & 0.27 & 1.0 & 1.03 & 1.03 & 0.00 & 0.48 & 0.74 & 0.74 & 0.00 & 0.58 & 0.68 & 0.69 & 0.30 & 0.18 \\
\hline $\begin{array}{l}\operatorname{LSD}_{(0.0} \\
5)\end{array}$ & NS & NS & NS & NS & NS & NS & NS & NS & NS & NS & NS & NS & NS & NS & NS & NS & NS & NS \\
\hline
\end{tabular}

Table 3: Pre-planting Treatment by Physiological Age (P x PA) of Cutting Interaction on Days to Breaking of First Bud and Shoot Development of the Cuttings.

\begin{tabular}{llll}
\hline Cuttings & Treatments & Days to breaking of first bud & Days to shoot development \\
\hline Semi-hardwood & Control & 7.5 & 9.3 \\
& Water & 6.1 & 7.4 \\
& Coconut water & 11.5 & 13.9 \\
Softwood & Control & & 11.5 \\
& Water & 9.3 & 12.2 \\
& Coconut water & 9.5 & 13.2 \\
& LSD $_{(0.05)}$ & 10.1 & $\mathrm{NS}$ \\
\hline $\mathrm{NS}$ & & & $\mathrm{NS}$ \\
\hline
\end{tabular}

Number of leaves per shoot showed significant ( $\mathrm{p}<$ 0.05 ) variation at each week of measurement in favour of softwood cuttings. Number of roots per cutting and longest root per cutting did not vary sigmficatly $(p>0.05)$ between softwood and semihardwood cuttings when measured at 8WAP. However, in both attitudes softwood cuttings still showed a clear tendency to do better. All attributes considered under pre-planting treatment were not significantly affected even though there were some obvious variations, see for example, Plate2 showing variation in rooting pattern as influenced by the pretreatment. Nevertheless, values for water tended to be higher especially with respect to percent cuttings with shoot, number of shoots per cutting and length of vine per cutting. It was observed that the effect of the pre-planting treatment was not consistent for all cuttings with similar treatment. Table 3 presents results of interaction between physiological age of cuttings and pre-sowing treatment on days to breaking of first bud and days to shoot development. Interaction of factors did not significantly influence these traits. Interaction between the factors had significant influence on percent cuttings with shoot and number of shoots per cutting (Table 4). At 4 8WAP semi-hard wood cuttings gave higher number of shoots per cutting when dipped in water. At 2WAP (the earliest time of measurement), control cuttings exhibited superior performance, producing more shoots per cutting in contrast to other treatments that gave zero shoots per cutting. With soft wood cuttings however, coconut water did better 
at 2WAP and showed superior tendency in performance $6-8 \mathrm{WAP}$. Interaction of factors could not elicit any significant response in number of shoots per cutting. Interaction was similarly not significant on length of vine, number of leaves, number of roots per cutting and length of longest root per cutting (Table 5). It was notable that at 2WAP, vine length of semi - hard wood cuttings was zero.

Table 4: Physiological age of cuttings by pre-planting treatment interaction on percentage of cuttings with shoot and number of shoot per cuttings over the eight weeks after planting (8 WAP).

\begin{tabular}{|c|c|c|c|c|c|c|c|c|c|}
\hline \multirow[t]{2}{*}{ cuttings } & \multirow[t]{2}{*}{$\begin{array}{l}\text { Pre-sowing } \\
\text { treatments }\end{array}$} & \multicolumn{4}{|c|}{$\%$ of cuttings with shoot over 8 WAP } & \multicolumn{4}{|c|}{$\begin{array}{l}\text { Number of shoots/cuttings } \\
\text { over 8WAP }\end{array}$} \\
\hline & & 2 & 4 & 6 & 8 & 2 & 4 & 6 & 8 \\
\hline \multirow{3}{*}{$\begin{array}{l}\text { Semi- } \\
\text { hardwood }\end{array}$} & Control & 26.7 & 53.3 & 53.3 & 66.7 & 0.13 & 0.67 & 0.67 & 0.67 \\
\hline & Water & 0.00 & 86.7 & 86.7 & 86.7 & 0.00 & 1.10 & 1.0 & 1.0 \\
\hline & $\begin{array}{l}\text { Coconut } \\
\text { water }\end{array}$ & 0.00 & 46.7 & 53.3 & 53.3 & 0.00 & 0.53 & 0.6 & 0.60 \\
\hline \multirow[t]{4}{*}{ Softwood } & Control & 26.7 & 80 & 93.3 & 93.3 & 0.77 & 1.13 & 1.13 & 1.13 \\
\hline & Water & 33.3 & 80 & 93.3 & 93.3 & 0.53 & 1.33 & 1.47 & 1.47 \\
\hline & $\begin{array}{l}\text { Coconut } \\
\text { Water }\end{array}$ & 40 & 80 & 100 & 100 & 0.53 & 1.47 & 1.47 & 1.47 \\
\hline & $\operatorname{LSD}_{(0.05)}$ & 14.53 & NS & 23.72 & 23.72 & NS & NS & NS & NS \\
\hline
\end{tabular}

WAP=weeks after planting; NS - No significant difference

TABLE 5: Physiological age by pre-planting treatment $(\mathbf{P A} \times \mathbf{P})$ of cutting interaction on length of vine and number of leaves over the 8WAP.

\begin{tabular}{|c|c|c|c|c|c|c|c|c|c|c|c|}
\hline \multirow[t]{2}{*}{ Cuttings } & \multirow[t]{2}{*}{$\begin{array}{l}\text { Pre-sowing } \\
\text { treatments }\end{array}$} & \multicolumn{4}{|c|}{$\begin{array}{l}\text { Length of vine }(\mathrm{cm}) \text { over } \\
\text { the 8WAP }\end{array}$} & \multicolumn{4}{|c|}{ Number of leaves over the 8WAP } & \multirow[t]{2}{*}{$\begin{array}{l}\text { Number of } \\
\text { shoots/cutting } \\
\text { at 8WAP }\end{array}$} & \multirow[t]{2}{*}{$\begin{array}{l}\text { Length of longest } \\
\text { root/cutting at } \\
\text { 8WAP }\end{array}$} \\
\hline & & 2 & 4 & 6 & 8 & 2 & 4 & 6 & 8 & & \\
\hline \multirow{3}{*}{$\begin{array}{l}\text { Semi- } \\
\text { hardwood }\end{array}$} & Control & 0.00 & 0.53 & 0.87 & 0.87 & 0.00 & 0.41 & 0.77 & 0.82 & 0.80 & 1.09 \\
\hline & Water & 0.00 & 0.73 & 0.73 & 0.93 & 0.00 & 0.57 & 0.65 & 0.83 & 0.00 & 0.45 \\
\hline & $\begin{array}{l}\text { Coconut } \\
\text { water }\end{array}$ & 0.00 & 0.33 & 0.67 & 0.67 & 0.00 & 0.33 & 0.63 & 0.65 & 0.00 & 0.00 \\
\hline \multirow[t]{4}{*}{ Softwood } & Control & 0.13 & 0.69 & 0.81 & 0.96 & 0.13 & 1.4 & 1.4 & 1.67 & 1.12 & 2.77 \\
\hline & Water & 0.07 & 0.85 & 0.90 & 0.90 & 0.33 & 1.4 & 1.4 & 1.4 & 0.87 & 0.90 \\
\hline & $\begin{array}{l}\text { Coconut } \\
\text { water }\end{array}$ & 0.00 & 0.63 & 0.81 & 0.81 & 0.00 & 0.73 & 0.84 & 0.93 & 0.60 & 0.37 \\
\hline & $\operatorname{LSD}_{(0.05)}$ & NS & NS & NS & NS & NS & NS & NS & NS & NS & NS \\
\hline
\end{tabular}

$\mathrm{NR} / \mathrm{C}=$ number of root per cutting; LLR/C = length of longest root per cutting; NS - No significant difference

\section{DISCUSSION}

The superiority of soft wood cuttings in terms of shoot and to some extent, root growth, is in line with what is commonly known. Juvenile tissues are generally known to root easily in contrast with hardened tissues (Leakey and Akinnifesi, 2008). In tree species, more than $90 \%$ are said to be amenable to propagation by softwood cuttings (Leakey, 1990). Although the use of mature tissues is credited with certain advantages, the extreme difficulty involved in propagating them through stem cuttings is a major drawback, compelling recourse to other methods namely grafting and budding (Hartmann et al., 2002). It is obvious that in African walnut, grafting and budding may not be feasible given that the species is a climber. Fortunately, it lends itself more easily to propagation by soft wood cuttings. Generally, use of stem cuttings in propagation circumvents the need for technical competence involved in the other propagation methods particularly grafting and budding. Propagation by softwood cuttings seem to occupy a prominent place in ornamental horticulture since in many of the species the method is preferentially adopted even in the face of modern tissue culture techniques (Agampodi and Jayawardena, 2009).

As stated earlier, propagation by seed does not seem to be a problem in conophor nut. However, as with other species, propagation by the use of vegetative parts may become imperative under certain circumstances. This include the need to propagate superior germplasm; the need for product uniformity to meet particular market requirements and avoidance of the longer period involved in conventional breeding (Leakey and Akinnifesi, 2008). In Plukenetia conophora, preliminary evaluations in Nigeria have already established superior germplasm sources with respect to seed proximate and some mineral properties (Agbo and Baiyeri, 2011). The high fat and protein content of 
the seed of this species have already instigated the opinion that it is a candidate for commercial exploitation (Agbo and Baiyeri, 2011). Consequently, once market demands are established propagation by soft wood cuttings could go a long way in creating new cultivars that would meet such specifications. It takes about three years for the conophor plant to initiate reproductive growth (Jiofack et al., 2013); propagation by soft wood cuttings would certainly accelerate the process.

In this species, the main effects of pre-planting treatment did not show any marked effect on any of the attributes examined. Results of interaction of the factors revealed a more favourable response of soft wood cuttings over the semi hard type. Generally, coconut water is endowed with a lot of plant growth regulators including IAA (Agampodi and Jayawardena, 2009). In the present study, the percent of cuttings producing shoots were statistically similar irrespective of pre-treatment In the case of semihardwood cuttings, those dipped in water produced the best result compared with control cuttings and those that were dipped in coconut water. Although, soft wood cuttings dipped in coconut water had a close to $7 \%$ performance above the other treatments, this may be considered too marginal to warrant the extra cost of sourcing for, and applying coconut water. The better performance of semi-hardwood cuttings dipped in water over those dipped in coconut water may appear contrary to expectations. It only serves to indicate that, in situations where only semihardwood cuttings must be used, cuttings could be dipped in water rather than coconut water. The cheapness associated with this activity makes it worthwhile.

In conclusion, this study has established the ease of vegetative propagation of Plukenetia conophora using soft wood cuttings. However, where semihardwood cuttings are involved dipping of cuttings in water may enhance the success of the activity.

\section{REFERENCES}

Agampodi, V. A. and Javawardena, B. Effect of coconut (Cocos nucifera L.) water extracts on adventitious root development in vegetative propagation of Dracaena purplecompacta L. Acta Physiologiae Plantarum 2009, 31: 279-284

Agbo, E. A. and Baiyeri, K. P. Proximate and mineral composition of fresh seeds of five accessions of African walnut (Plukenetia conophorum Muell Arg), pp. 294 - 297. In: Proceedings of the $29^{\text {th }}$ annual conference of the Horticultural Society of Nigeria, $24^{\text {th }}$ $-29^{\text {th }}$ July, 2011. University of Agriculture, Makurdi, Benue State, Nigeria.

Ajaiyeoba, E. O. and Fadare, D. A. Antimicrobial potential of extracts and fractions of the African walnut - Tetracarpidium conophorum. African Journal of Biotechnology 2006, 5: 2322-2325

Akpuaka, M. U. and Nwankor, E. Extraction, analysis and utilization of drying-oil

from Tetracarpidium conophorum. Bioresour. Technol. 2000, 73:195-196.

Amaeze, O. U., Ayoola, G. A., Sofidiya, M. O. Adepoju-Bello, A. A., Adegoke, A. O. and Coker, H. A. B. Evaluation of antioxidant activity of Tetracarpidium conophorum (Müll. Arg) Hutch \& Dalziel leaves. Oxidative Medicine and Cellular Longevity, vol. 2011, Article ID 976701, 7 pages, 2011. doi:10.1155/2011/976701

Ayoola, P. B., Adeyeye, A., Onawumi, O. O. and Faboya, O. O. Phytochemical and nutrient evaluation of Tetracarpidium conophorum (Nigerian walnut) root. IJRRAS 2011, 7: 197-202

Babalola, F.D. Cultivation of African walnut Tetracarpidium conophorum mull. (arg) on agricultural plantation: an approach to conservation agriculture in Nigeria. 5th World Conference on Conservation Agriculture and $3^{\text {rd }}$ Farming Systems Design (WCCA/FSD), Brisbane, Australia from 26-29 September 2011. 180-181Pp

Egharevba, R. K., Ikhatua, M. I., and Kalu, C. The influence of seed treatments and growing media on seedling growth and development of African walnut, Plukenetia conophorum. African Journal of Biotechnology 2005, 4:808-811

Enujiugha, V. N. Chemical and functional characteristics of conophor nut. Pakistan Journal of Nutrition 2003, 2: 335-338.

Gbadamosi, S. O., Abiose, S. H. and Aluko, R. E. Solubulization, amino acid composition and electrophoretic characterization of Conophor nut (Tetracarpidium conophorum) proteins. International Food Research Journal 2012, 19: 651-656.

GENSTAT. Genstat 7.22.0 Release 3 DE Discovery Edition, Lawes Agricultural Trust, Rothmanisted Experimental Station, UK, 2008.

Jiofack, T., Tchoundjeu, Z., Guedje, N. M., Lejoly, J., Fokunang, C. and Mate, M. Can the contribution of African walnut diversifying cocoa agro forests being profitable for local stallholders in Cameroon? Wudpecker Journal of Agricultural Research 2013, 2: 142-150.

Kozlowski, T. T. Growth and Development of Trees, Vol 2. Academic Press, New York, 1971.

Leakey, R. R. B. Agroforestry: A Delivery Mechanism for Multi-Functional Agriculture, In: Kellimore, L. R. (Ed.) 
Handbook on Agroforestry: Management Practices and Environmental Impact. Nova Science Publishers, New York, 2009. 461471Pp.

Leakey, R.R.B. and Akinnifesi, F.K. Towards a domestication strategy for indigenous fruit trees in the tropics. In: Indigenous Fruit Trees in the Tropics: Domestication, Utilization and Commercialization, 28-49, F.K. Akinnifesi, R.R.B. Leakey, O.C. Ajayi, G, Sileshi, Z. Tchoundjeu, P. Matakala, and F. Kwesiga (eds), CAB International, Wallingford, UK, 2008.

Okafor, J. C. and Okorie, P. E. Environmental and ethnobotanical importance of the tropical rainforest in Nigeria. Proc. $4^{\text {th }}$ Annual Conference of the Botanical Society of Nigeria, Nsukka, 1990.

Oladokun, M. A. O. and Ajolo, A. P. Effects of growth regulator on rooting of some ornamentals in south western Nigeria. Proceedings, $14^{\text {th }}$ Horticultural Society of Nigeria Conference, Ago-Iwoye, $1-4$ April, 1996. Pp. 316 - 324 